\title{
A „Nóra-jelenség” és az ibsenizmus szerepe a 20. századi kínai dráma fejlődésében
}

\section{Bevezetés}

Henrik Ibsen (1828-1906) norvég drámaírót az utókor a modern kori drámaírás atyjaként tartja számon. Színdarabjai egytől egyig megrázó erejüek, nagy hatásúak, munkásságát mindenkor nagy figyelem övezte. Drámáiban felvállalt erkölcsi álláspontja nemegyszer megosztotta a norvég (és az európai) közvéleményt, és heves társadalmi vitákhoz vezetett, müvészi értéküket azonban senki nem vitatja. Darabjait nem sokkal megírásuk után már Európa-szerte játszották, de nyugati szerzők között példátlan az a hatás, amelyet nem sokkal halála után Ibsen Kínában kiváltott.

A 19. század közepén Norvégia a kibontakozó kapitalizmus áldásait élvezi, ugyanakkor annak negatív hozadékaival küzd. Ibsen ebben a társadalmi közegben él és alkot: realista drámái tükröt tartanak azoknak a társadalmi fonákságoknak, amelyek meggyőződése szerint a kapitalista fejlödés során elkerülhetetlenül megjelennek, és bizonyos emberi jellembeli torzulásokat okoznak. Kína a 20. század elején még nem lépett a kapitalizmus korszakába, a császári örökség és a modern kori fejlődés között egyensúlyoz. Mi az, ami miatt egy merőben más kulturális és társadalmi háttérből származó, Kína számára addig szinte ismeretlen nemzetiségü drámaíró ekkora népszerüségre tudott szert tenni egy ilyen távoli országban? Minek köszönhetően tudott ilyen maradandó hatással lenni egy ekkora nemzet irodalmi és kulturális életére? Abban, hogy ez így alakulhatott, nagy szerepet játszott a történelem.

A 19. század középső harmadában Kína először szembesült a nyugati világ katonai fejlettségével. Az ópiumháborúkban elszenvedett megalázó vereségek aláásták a kínaiaknak a Középső Birodalom gazdasági, társadalmi és morális felsőbbrendüségébe vetett hitét. Kína kikötőinek kikényszerített megnyitása, a kereskedelem megindulása elsősorban a nyugati érdekeket szolgálta, Kína számára előnytelen kompromisszumokkal járt. A kínaiakban egyre nőtt az elégedetlenség a császári vezetéssel kapcsolatban, amely tehetetlennek tünt 
az erőszakos nyugati befolyással szemben. A Qing-dinasztia 清 (1644-1911) a veszély ellenére luxusra tékozolta az állami vagyont, Kínát pedig továbbra is kiszolgáltatta a nyugati hatalmaknak és Japánnak. Az alávetett tömegek soraiban gyülemlett a feszültség, lázadások követték egymást.

Az első világháború után Kína egyenlőtlen békeszerződés aláíása előtt állt; az 1919-es versailles-i egyezmény területileg komolyan megcsonkította volna. Ez a kilátás szikra volt a puskaporos hordónak. Május 4-én Pekingben a diákság hatalmas tömegben vonult az utcára, és hevesen tiltakozott az egyezmény aláírása ellen, amely szemükben Kína végső megaláztatását jelentette volna. Az úgynevezett „május negyedike mozgalom” (wusi yundong 五四运动) országos méretűvé nőtte ki magát, és a reformok, a demokrácia, a társadalmi és kulturális megújulás szellemi programját tette magáévá. A békeszerződést végül nem írták alá, de a változásokhoz több időre volt szükség.

Kína a katonai vereségek hatására kénytelen volt megkezdeni a nyugati „praktikus tudományok” (pl. nehézipar, hadiipar) tanulmányozását. Az „önerősítés” (ziqiang 自强) programjának híres jelszava: „A kínai ismeretek fundamentum gyanánt, a nyugatiak gyakorlati célokat szolgáljanak!"” (Zhongxue wei ti, xixue wei yong! 中学为体, 西学为用!) Másban nem érezték szükségét a Nyugattól tanulni. Az eszmék áramlását azonban nem lehetett államilag korlátozni: a fejlett technikai ismeretek mellett sok nyugati ideológia is utat talált Kínába. A fiatal kínai értelmiség hite már egy ideje megingott a régi eszmékben, amelyek addig életüket irányították. Ezeket elmaradottnak kezdték látni, és ez fogékonnyá tette őket a nyugati eszmerendszerek iránt. Úgy tünt, a nyugati értékek: a demokrácia, az egyéniség szellemi szabadsága mind hatásos fegyverek lehetnek a Kínában évezredek óta uralkodó konfuciánus eszmerendszer megdöntéséért vívott harcban. A fiatalok úgy érezték, míg a világ fejlödött, Kína megragadt a múltban. Most minden figyelmükkel a Nyugat felé fordultak, lelkesen azonosultak a gondolatokkal, amelyeket modernnek és haladónak láttak. Hitték, hogy ebben rejlik Kína felemelkedésének reménye.

Már a századforduló körül kezdtek kibontakozni a kínai irodalom megújítására irányuló törekvések. Ami a társadalomban a merev konfuciánus hierarchia, az volt az irodalomban a klasszikus kínai nyelv (wenyan 文言): archaikus jelenség, a fejlődés gátja. Elsősorban ez lett tehát a támadások célpontja. Helyébe a közérthető, élőszóhoz közelálló baihua 白话 nyelvet propagálták,

1 Galla 1986: 1355. 
amely hamar teret hódított. Irodalmi társaságok, folyóiratok alakultak, soha nem látott módon megélénkült az irodalmi élet. A fiatal haladó értelmiség úgy gondolta, hogy az irodalomnak a puszta szórakoztatásnál magasabb célt kell szolgálnia: ha közérthető formába öntik, ez lehet az új társadalmi eszmék terjesztésének leghatásosabb eszköze.

Az új nyelvezetnek és az új mondanivalónak új formával kellett párosulnia. A hagyományosan domináns líra, bár nem vált mellőzötté, átmenetileg háttérbe szorult. Fontos szerephez jutott a novella, de a legnagyobb, tömegeket megszólító ereje a drámának volt. A hagyományos kínai színjátszás vásári jellegénél fogva mindig is sokakat vonzó, szórakoztató müfaj volt, és mint ilyen, ha népszerüségnek örvendett is, müvészi presztízsnek nemigen. ${ }^{2}$ A dráma fontos társadalmi küldetés előtt állt, ehhez azonban először formai megújulásra volt szükség.

Az akkori kínai értelmiség úgy érezte, a tradicionális kínai színházmüvészet - hagyományos formanyelve, előadói sajátosságai miatt - nem alkalmas új társadalmi eszmék közvetítésére. A nyugati irodalmat már egy ideje aktívan tanulmányozó irodalmárok a nyugati drámai formában látták a megoldást a problémára. A fiatal kínai drámaírók kísérletezni kezdtek, és ezáltal fokozatosan meghonosították a kínai irodalomban a nyugati drámai formát. Mivel ebben a szereplők prózában kommunikálnak egymással, ez a fajta dráma a huaju 话剧, vagyis ,,beszélt dráma” néven vált ismertté.

Voltak, akik a teljes megújulás hívei lévén gyökeresen fel akarták számolni a kínai színházmúvészet - általuk dekadensnek ítélt - hazai hagyományait, és annak helyébe átvenni a nyugati drámát. Mások, például a kor jelentős drámaírója, Tian Han 田汉 (1898-1968) nem osztották ezt a nézetet. Ök úgy vélték, hogy a modern kínai drámaíróknak igenis van, amit érdemes megtanulni a hagyományos színház müvészetéből. Hirdették, hogy a színház modernizálása nem jelentheti a nemzeti karakter elvesztését, csakis a kettő ötvözése vezethet sikerre. 2004-ben megjelent könyvében He Chengzhou három jelentős erőt nevez meg, amelyek egyensúlyától a modern dráma felemelkedése függött: a nyugati hatást, amelyet kapott, a kulturális szerepet, amelyet be kellett töltenie, és a színház nemzeti hagyományait, amelyeket be kellett építenie. ${ }^{3}$

Ebbe a felpezsdült szellemi közegbe robbant be Ibsen.

2 Meg kell jegyezni, hogy ez alól kivételt képeztek a magánszínházak, amelyek magas színvonalú, megbecsült szórakoztatást nyújtottak nemesi udvarok számára.

3 He 2004: 107. 
Ahogy a kulturális megújhodást is sürgető május negyedike mozgalom egyre inkább kibontakozott, az új eszmék, gondolati irányzatok egymást követve áramlottak be a szellemi életbe. Gyors egymásutánban születtek a nyugati müvek fordításai: Tolsztojt, Turgenyevet, Zolát, Maupassant-t, Dickenst, Tagorét tanulmányozták. Érdeklődésük korántsem szorítkozott a fejlett nagyhatalmakra, hanem különösen élénk volt olyan kis népek irodalma iránt, amelyek valamiféle elnyomás alatt éltek, és nemzeti irodalmukban az ez elleni lázadást juttatták kifejezésre. ${ }^{4}$ Ibsen, bár „kis” nép fia, már életében Európa-szerte elismert drámaíró volt, így érthető, hogy híre eljutott Kínába. De mi lehetett az oka annak, hogy számos nagy írótársa mellett mégis ő lett a legnagyobb hatással a modern kínai drámairodalomra?

A Kínában társadalmi és gazdasági szempontból alávetetten élő tömegek az utóbbi évtizedek eseményeinek hatására kezdtek rálátni helyzetükre, és egyre méltatlanabbnak érezni azt; nőni kezdett az igény a szűk kormányzó elittől való függés megszüntetésére. A társadalmon belül is voltak azonban súlyos különbségek. Li Dazhen 李大钢 a 20. századot ,a társadalmi osztályok és az egyének mindenfajta elnyomás alóli felszabadulása időszakának" ${ }^{35}$ nevezte. A nőket Kínában addig egyáltalán nem vették számba mint társadalmi csoportot. Ennek a korszaknak a nyugati eszmei hatásokkal teli szellemi közegéhez köthető, hogy a „nyugatos” értelmiség elkezdett rájuk ekként tekinteni.

A nők jogait követelő hangok Európában már a 17. században megjelentek, de a feminizmus igazi kibontakozása a 19. század második felére tehető. Ez az az időszak, amikor a történelmi fejlődésben egyik társadalom a másik után jutott el a demokratizálódás szakaszába, amikor is az eredetileg a társadalmi osztályok között fennálló különbségek - inkább jogi, mint pénzügyi értelemben - csökkentek vagy megszüntek. Ilyen körülmények között egyre természetellenesebbnek és fenntarthatatlanabbnak tünt a nők társadalmilag és politikailag alárendelt helyzete.

Kínában azonban a Nyugathoz képest ez a folyamat jóval több akadályba ütközött. A nők helyzete a régi Kínában összehasonlíthatatlanul rosszabb volt, mint nyugaton. Az ő szempontjukból a 20. század eleje még a régi, feudális Kína időszakához tartozott. A társadalmi rendszert évezredek óta minden rész-

4 Ekkorra tehető az is, hogy a kínaiak „felfedezték” Petőfi Sándort, hiszen nagy költőnk forradalmi heve, meg nem alkuvó szabadságvágya csodálatra méltó volt a szemükben. Szinte egész életművét lefordították kínaira, és máig sokan ismerik a nevét.

5 Gao 2006: 66. 
letre kiterjedően a konfuciánus ideológia határozta meg. A politikai, gazdasági és kulturális élet irányítása a kínai társadalomban mindig is a férfiak kezében összpontosult. A nők ezzel szemben alárendelt szerepet játszottak, és semmiféle jogot nem élveztek. Mindennapi életüket, a tőlük elvárt viselkedést számtalan szabállyal korlátozták. Nem túlzás azt állítani, hogy a konfuciánus etika a szó legszorosabb értelmében megfojtotta a nők egyéni szabadságát. ${ }^{6}$ Mindezek ismeretében nem meglepő tehát, hogy Ibsen önmagát felszabadító Nórája a kínai nők szemében (is) ikonná vált.

\section{A „Nóra-jelenség” és az ibsenizmus}

Ibsen Babaház (1879) címü darabja egy tisztes, középosztálybeli norvég családról szól. A férjet, Torvald Helmert újonnan nevezték ki a bank élére, felesége, a fiatal, életvidám Nóra neveli három szép gyermeküket. Bár Helmer kissé atyáskodni tünik neje fölött, férj és feleség kapcsolata szeretetteljes. A család élete idillinek látszik. Nóra barátnőjének, Lindénének vall egy régi titokról, amely boldogságára fenyegető árnyékként borul. Évekkel ezelőtt váltót hamisított, hogy édesapja nevében pénzt szerezzen, és nagybeteg férjét külföldre tudja utaztatni a gyógyulás érdekében. Helmer önérzetes ember, aki nem fogadta volna el az ilyen segítséget, ezért Nórának titokban kellett cselekednie. Férje meggyógyult, Nóra pedig titokban, apránként törleszti tartozását.

A konfliktus akkor kezd kibontakozni, amikor feltünik az alattomos Krogstad, Nóra hitelezője, és tartozása fejében azt kéri az asszonytól, segítsen neki megtartani bankbéli állását, mivel férje éppen el akarja bocsátani. Az asszony félelmetes válaszút elé kerül: vagy protekciót szerez szakmailag feddhetetlen férjénél a rossz hírü Krogstadnak, vagy az felfedi titkát. Megpróbál férjénél közbenjárni, de hiába, a titok pedig nem maradhat sokáig rejtve.

Mikor Helmer értesül felesége múltbéli „üzelmeiről”, reakciója lesújtó. Nóra háromnapos őrlődése derüsebb pillanataiban azt remélte, férje kiáll mellette, és tettét megértve hálás lesz felesége áldozatos szerelméért. Helmer azonban nemhogy nem hálás, semmiféle sorsközösséget nem vállal Nórával: „kétszínü, elvetemült hazugnak”7 nevezi, aki miatt az ő szakmai és emberi

Zhang 2004: 120.

Ibsen 1966: 488. 
feddhetetlenségének, boldog életének örökre vége. Gyermekeiket is el akarja különíteni Nórától, hiszen a hazugság „megmérgezi az otthont, megrontja a gyerekeket". ${ }^{8}$ Nóra összeomlik.

Az események hirtelen fordulatot vesznek, ugyanis Lindéné hatására (aki, mint kiderül, Krogstad régi szerelme) Krogstad jobb belátásra tér, és felmenti Nórát minden kötöttség alól. Helmer ujjong, és keblére ölelné feleségét, aki azonban hideg marad. Számára nem hoz megkönnyebbülést a veszély elhárulta, a baj már megtörtént. Keservesen csalódnia kellett férje szeretetében, amely a válságban nem állta ki a próbát. Elveszítette az illúziót, hogy boldog volt egy ilyen házasságban, ahol ő ennyire súlytalannak találtatott. Rádöbben, hogy mindvégig csupán férje „babája” volt, sosem valódi, megbecsült társa.

Helmer nem érti, Nóra miért nem örül vele együtt a dolgok e szerencsés fordulatának, és a zavartalan jövőnek, ami most így előttük áll. Nóra komoly beszélgetést kezdeményez, amely, mint rámutat, az első ilyen a házasságuk

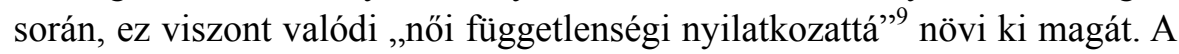
felismeréssel, amelyben most része volt, nem élheti tovább eddigi életét. Elszámol férjével, elvág kettejük között minden köteléket. Helmer azt hiszi, felesége megháborodott, Nóra viszont döntött. Anélkül, hogy tudná, mi lesz vele, becsapja maga mögött az ajtót, és örökre elhagyja a „babaházat”.

„A Babaház utolsó jelenetében a Nóra mögött becsapódó ajtó döreje megrengette a 19. századi Európát, és ennek visszhangját még a 20. századi Kínában is lehetett hallani”"10 - fogalmaz a „Nóra-jelenséget” elemző cikkében Zhang Lansheng 张兰生. A Babaház 1879-es koppenhágai bemutatója végletes reakciókat váltott ki a közönségből és a kritikusokból. Még a kortárs Európában is hallatlan erkölcstelenségnek számított, hogy egy asszony elhagyja férjét és gyermekeit, hát még később, a szélsőségesen konzervatív társadalmú Kínában.

A Babaházat (Wan'ou zhi jia 玩偶之家) Kínában eleinte mükedvelő vagy iskolai színtársulatok vitték színre, korlátozott számú közönség előtt. A darab az első pillanattól megosztotta a kínai közönséget: kiből megbotránkozást, kiből lelkes rajongást váltott ki, de közömbös senki sem maradt iránta. Sokan nem voltak képesek befogadni a darab mondanivalóját, és felháborodva kérdezték: vajon mi a baj Helmerrel, ezzel a derék, becsületes férjjel és csa-

\footnotetext{
Ibsen 1966: 456.

Yu 2013: 136.

Zhang 2005: 33.
} 
ládapával? Miféle könnyelmü teremtés ez a nő, hogy egy nézeteltérés miatt elhagyja a családját?

Azok azonban, akik messzebbre láttak, és kevésbé voltak megkötve a hagyományos kínai erkölcsi beidegződések által, Nóra tettét bátornak és hősiesnek látták. Alakja szimbólum lett a 20. század eleji Kínában: az új értékrend, az egyéniség lázadása, a szellemi szabadság megtestesítője, az Új Nő maga. Modernsége, meg nem alkuvása milliók szemében vált követendő példává. Ibsen $A$ nép ellensége (1882) címü darabját is müsorra tüzték és sikerrel játszották, a Babaház sikere azonban elsöprő és megismételhetetlen volt. Az előadásokat óriási közönség- és sajtóvisszhang fogadta, mindenhol írtak, beszéltek, vitatkoztak a darabról. Az 1920-30-as évek e heves irodalmi és erkölcsi diskurzusát nevezik „Nóra-jelenségnek” (Nala xianxiang 娜拉 现象), amely fontos szerepet játszott a modern kínai dráma fejlődésében.

A darab fordítása először 1918-ban jelent meg folytatásokban az egyik legjelentősebb folyóiratban, a haladó eszméket hirdető Új ifjúságban (Xin qingnian 新青年). Az a Hu Shi 胡适 (1892-1962) fordította, aki a lap fószerkesztője és egyben az új kultúra mozgalom egyik fontos szellemi vezetője volt. A Babaház egyedülálló népszerüségét mutatja, hogy az ezután következő három évtizedben kilenc különböző fordítása jelent meg, több, mint bármely más nyugati irodalmi münek. ${ }^{11} \mathrm{Az}$ Új Ifjúság e számaihoz $\mathrm{Hu} \mathrm{Shi}$ „Ibsen-különszámot” (Yibusheng zhuanhao 易卜生专号) adott ki, amelybe egy cikket is írt Ibsenizmus (Yibusheng zhuyi 易卜生主义) címmel, a kínai közönségnek bemutatva és méltatva a szerzőt. Az ibsenizmus kifejezést először George Bernard Shaw használta; valószínünek tűnik, hogy Hu Shit az ő 1913-ban írt esszéje, Az ibsenizmus kvintesszenciája lelkesítette fel. ${ }^{12}$

$\mathrm{Hu}$ Shi cikke meghatározó hatással volt Ibsen kínai fogadtatására a következő évtizedekben. Köztudott, hogy a modern kínai novella legnagyobb mestere, Lu Xun 鲁迅 (1881-1936) már 1908-ban írt két cikket, amelyben Ibsent a kínai olvasók és színházkedvelők figyelmébe ajánlotta, de $\mathrm{Hu}$ Shi Ibsenizmusának jelentősége sokak szerint „korszakalkotó”, „közvetlenül jelenti a modern kínai irodalom új eszmevilágának kezdetét"13. Hu Shi volt az, aki ezen írásával megfújta az új kor harsonáját. ${ }^{14}$ Hatására a kínaiak szemében

11 He 2004: 23.

12 He 2004: 19. Ibsennek Shaw-ra tett hatásáról lásd pl. Chen - Li 2006.

13 Song 2011: 122.

14 Song 2010: 190. 
Ibsen lett az irodalmi forradalom, a női emancipáció, az elavult gondolkodással való szembefordulás, az Egyéniség jelképe,${ }^{15}$ így magyarázta ugyanis Hu Shi az ibsenizmus terminust. Hu Shi cikkében így definiálja az egyéniség fogalmát:

„Egy autonóm társadalom vagy köztársaság meg kell, hogy adja az egyénnek a választás szabadságát, ugyanakkor felelőssé is kell tennie őt saját tetteiért. Enélkül lehetetlen a függetlenség. Egy társadalom vagy ország pedig független egyének nélkül olyan, mint a bor alkohol nélkül, a kenyér kovász nélkül, vagy az emberi test agy nélkül. Egy ilyen társadalomnak semmi reménye a haladásra." ${ }^{\prime 16}$

A cikk jelentősége messze túlmutat mủvészi értékén: ahogy Song Linsheng 宋林生 fogalmaz: „Hu tábornok Ibsenizmusa az irodalmi forradalmi hadsereg nyila, amely az elavult dráma vára felé süvít." ${ }^{, 17}$ Széleskörủ szakirodalom méltatja, ,,a modern kínai dráma megújulásának egyik klasszikus dokumentumaként"18 tartják számon.

1925-ben a 20. századi kínai regény nagy alakja, Mao Dun 矛盾 (18961981) $A$ Nóráról címü esszéjében így írt erről: „Hét évvel ezelött, az »Ibsenkülönszám « megjelenésekor Ibsen neve visszhangzott a fiatalok fülében, nevét jelszóként adták szájról szájra, nem kisebb csodálattal, mint ma Marxét vagy Leninét." 19

He Chengzhou kiemeli: Ibsen müveinek kínai fordításai különlegesek abban az értelemben, hogy egyetlen egy sem alapszik az eredeti norvég szövegen, kivétel nélkül mind közvetítő nyelv segítségével készültek. ${ }^{20}$ William Archer (1856-1924) angol nyelvü fordításai hozzáférhetőek voltak, ezek alapján a müveket japán nyelvre is átültették. Az új irodalmi mozgalom több szellemi vezetője (pl. Hu Shi, Chen Duxiu 陈独秀, Tian Han) azelőtt külföldön (Angliában, az Egyesült Államokban, Japánban) tanult cserediákként, így ezek a fordítások könnyen szolgálhattak a kínaiak alapjául. Az 1920 30-as évek során Ibsen majdnem minden színdarabját lefordították. Legel-

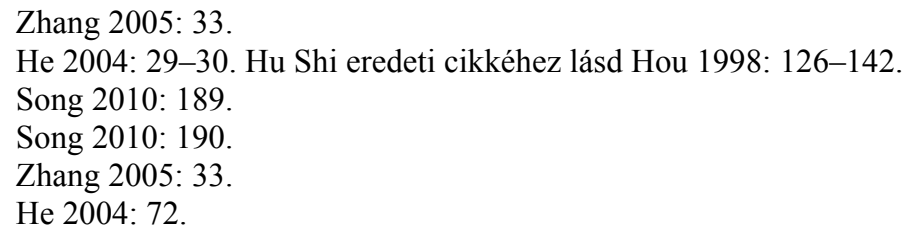


ismertebb kínai fordítói Pan Jiaxun 潘家洵 és Xiao Qian 萧乾 voltak, akik az angolból való fordítás veszélye ellenére minőségi munkát végeztek. ${ }^{21}$

A „Nóra-láz” nem akart szünni. Az 1935-ös év „Nóra-évként” került be a kínai köztudatba, mivel ebben az esztendőben az eddiginél is sürübben adták elő a darabot, Kína számos nagyvárosában egymást érték a bemutatók. (Időközben a Babaház címet elhagyták, és a darab a mindenki fülében ismerősen csengő Nóra - Nala 娜拉 - néven futott.) Az előadások nemegyszer politikai zavargásba torkolltak, mivel a konzervatív és haladó erők szó szerint a színházban ütköztek meg egymással. He Chengzhou nagyhatású, Henrik Ibsen és a modern kínai dráma címü könyvében még egy nevezetes eseményt említ meg, amely ehhez az évhez köthető: A Nanjingban 南京 (az akkori fővárosban) tartott Nóra-bemutatót követően a Nóra szerepét játszó tanárnőt, Wang Pinget 王苹 az iskolaigazgató elbocsátotta állásából. Véleménye szerint Nóra tette semmilyen körülmények között nem megbocsátható, aki pedig szerepét eljátssza, azonosul vele. Ez így is volt, Wang kisasszony büszkén vállalta Nórát. Az eset természetesen óriási port kavart, vég nélkül cikkeztek róla az újságok, a nőtársaságok hevesen bírálták az igazgatót, az esemény pedig az 1935-ös „Nóra-incidens " néven vonult be a történelembe. ${ }^{22}$

Úgy gondolom, amikor a fiatal kínai író-értelmiség a 20. század elején úgy döntött, hogy a nyugati drámai formával kísérletezik kínai színpadon, összetett feladatot vállalt. Egyfelől a kínai drámaíróknak nem volt tapasztalatuk ebben a müfajban alkotni, másfelől a kínai közönségnek nem volt tapasztalata, hogyan kell ezt a fajta hatást befogadni. Az emberek a hagyományos kínai színházhoz voltak szokva, amely akrobata mutatványokkal, pergő szójátékokkal, látványos táncokkal és más hasonló elemekkel szórakoztatta a közönséget. A nyugati dráma ehhez képest statikus előadásmódját érdektelennek találták. Jó példa erre George Bernard Shaw Warrenné mestersége (1893) címü darabja, amely nyugati módon, ,hủen” előadott formában 1921-es shanghai-i bemutatóján csúfosan megbukott. Ezzel szemben 1924-ben Shanghaiban, Oscar Wilde Lady Windermere legyezöje címü vígjátéka, amelyet a kor egyik legjelentősebb drámaírója, Hong Shen 洪深 (1894-1955) az eredeti szöveget és cselekményt meglehetősen szabadosan kezelve alkalmazott színpadra, nagy sikert aratott. ${ }^{23}$ A tanulság egyértelmü

$\begin{array}{ll}21 & \text { He 2004: } 74 . \\ 22 & \text { He 2004: } 24 . \\ 23 & \text { He 2004: } 93 .\end{array}$ 
volt: a külföldi darabokat valamilyen mértékben a kínai közönség ízléséhez kell szabni.

Kínában a nyugati dráma 20. század elejére tehető megjelenésével bizonyos feszültség keletkezett. Két színházi megközelítés ütközött egymással, és több különböző ,hibrid” forma jött létre ennek a feszültségnek a feloldására. A modern dráma első formája, az ún. „felvilágosult színjáték” (wenming $x i$ 文明戏) még örizte a kínai színházmüvészetben hagyományosan jellemző oralitás dominanciáját, nem törekedett a hitelességre sem a szöveg, sem a cselekmény tekintetében. A szereplők nemegyszer még szöveget sem kaptak, csak a cselekményt vázolták fel nekik nagy vonalakban. A többi a színész dolga volt, aki a hagyományos kínai színpadon mindig is nagy önállósággal rendelkezett.

Az 1920-as években Ibsen drámáinak még mindig inkább a műkedvelő előadásai voltak túlsúlyban. 1929-ben Xiong Foxi 熊佛西 (1900-1965) Egyesült Államokban tanult drámaíró Pekingben megrendezte Ibsen Kísértetek (Qungui 群鬼) címü darabját - He Chengzhou szerint ezt a bemutatót nevezhetjük az „első kínai professzionális Ibsen-előadásnak”. ${ }^{24}$ Xiong esszét is publikált, melyben Ibsent a modern tragédia úttörőjének nevezi, és méltatja drámai müvészetét. Véleménye szerint Ibsen darabjainak egyetlen gyenge pontja van: a hosszadalmas párbeszédek, amelyek bár tartalmasak, a mozgalmas színpadi jelenetekhez szokott kínai közönséget nem tudják lekötni. „A $K i$ sértetek végignézéséhez gondolkodásra és türelemre van szükség, és ez éppen az a két dolog, amelyre a kínai közönség nem képes" ${ }^{25}$ - írja Xiong. He véleménye szerint Xiong Foxi meglátása a mai napig releváns tanulság, amelyet a nyugati darabok rendezésénél a mai kínai rendezőknek is észben kell tartaniuk. ${ }^{26}$

Mindeközben nemcsak játszották, újra is alkották a Nórát. Egymás után születtek a „Nóra-darabok”. Sok ambiciózus fiatal kínai drámaíró egyenesen élethivatásának tekintette, hogy „Kína Ibsenjévé” váljon. ${ }^{27}$ Tian Han kissé szerénytelenül „rügyező Ibsennek” ${ }^{28}$ nevezte magát. Az első jelentős modern kínai színdarabnak Hu Shi Legnagyobb dolog az életben (Zhongshen dashi 终身大事, 1919) címü egyfelvonásosát tartják. Általános kritikai nézet, hogy

\footnotetext{
24 He 2004: 93.

25 He 2004: 95.

26 He 2004: 93.

27 Zhang 2005: 33.

28 He 2004: 12.
} 
bár rövidségénél fogva nem ad módot mély jellemábrázolásra, és némileg a cselekmény is kidolgozatlan, a darab mégis fontos hatással volt az elkövetkezö évtizedek drámairodalmára: megnyitotta a "Nóra-darabok” hosszú sorát. ${ }^{29}$ Itt jelennek meg először azok a jellegzetes dichotómiák, amelyek végig meghatározók lesznek Kína Ibsen inspirálta irodalmában: a hagyomány és a modernitás, az elnyomás és az emancipáció, a család iránti kötelezettségek és az egyéni szabadság között feszülő ellentmondások. ${ }^{30}$

A felsorolhatatlanul sok „Nóra-darab” között említést érdemel még Ouyang Yuqian 欧阳予倩 A házsártos feleség (Pofu 泼妇, 1922) és Zhang Wentian 张闻天 Ifjúkori álom (Qingchun zhi meng 青春之梦, 1927) címü mủvei, továbbá Guo Moruo 郭沫若 Három lázadó nö (San ge panni de nüxing 三个叛逆的女性, 1924) címü trilógiája. He Chengzhou nem kevesebbet állít, mint hogy a modern kínai dráma többé-kévésbe a Babaház utánzásával kezdődött. ${ }^{31}$

Fontos megemlíteni, hogy Nóra alakja nem csupán a drámaírókat ihlette meg. Számos kis- és nagyepikai müben is találunk Nóra ihletésű szereplőt. He Chengzhou így idéz Pollard-tól: „Az 1920-as években nem volt olyan valamirevaló kínai író, aki ne foglalkozott volna a nők felszabadításának témájával, Nóra hatása pedig legtöbbször egyértelműen érződik a főhősnőkön." ${ }^{32} \mathrm{Lu}$ Xun maga is csodálta Ibsent. Ő elsősorban $A$ nép ellenségének Dr. Stockmannját tartotta olyan bátor, önálló egyéniségnek, amilyenekre Kínának nagy szüksége lenne. Egyik novellájának, az Elsiratásnak (Shangshi 伤逝, 1925) a hősnője, Zijun 子君 is magán viseli az ibseni jegyeket. Mao Dun is megírt ilyen hősnőt 1930-as Szivárvány (Hong 虹) címü regényében. A másik nagy regényíró, Ba Jin 巴金 (1904-2005) Család (Jia 家, 1931) című híres regényében különleges szereplővel járult hozzá a „Nórajelenséghez”, egy valódi „férfi Nórát” alkotva: a legfiatalabb fiú, Gao Juehui 高觉慧 úgy érzi, a patriarchális család merev szigora fojtogató súllyal nehezedik rá, és úgy dönt, otthagyja a Gao-házat. A hagyományos Kínában ez egy férfitól is, ha nem is erkölcstelen, mégis elfogadhatatlan lépés volt.

\footnotetext{
29 Li 2012: 59.

30 Sanderson 2010: 34.

31 He 2004: 24.

32 He 2004: 26.
} 


\section{A realista ábrázolás}

Ibsennek és a Nórának a sikere és tartós népszerüsége azonban nem pusztán a főhősnő alakjának köszönhető. Egy olyan korban, amikor a fiatal kínai értelmiségi nemzedék az irodalmat az emberek oktatásának és a társadalom jobbításának céljára kívánta felhasználni, érthető, hogy Ibsen realista drámái követendő példává tudtak válni. Ibsen hatása nem pusztán az ideológiai inspirációban mutatkozott meg; az új nemzedék úgy érezte, tanulhatnak tőle a drámaírás eszközeiről is. Mivel koruk problémáinak megoldásához széleskörü társadalmi diskurzusra volt szükség, a véleményük szerint reformra szoruló társadalmi valóságot hűen kellett szemléltetni a drámai színpadon. Ehhez a célhoz találták Ibsent fontos eszköznek.

A norvég drámaíró minden tekintetben arra törekedett, hogy darabjai hüek legyenek a valósághoz. Az általa elöírt színpadi díszletek aprólékosak, a kosztümök életszerủek voltak. A kínaiak számára ez szokatlan volt: a hagyományos kínai színházban minimális díszlettel dolgoztak, a színész gyakorlatilag el kellett, hogy játssza, maga kellett, hogy megjelenítse a tárgyakat, melyeket „használt”. Az új drámaírók azonban nem akartak véteni a valóság hü ábrázolása ellen, ezért darabjaikban követték a nyugati drámák részletes színpadi leírásait.

Ibsen első néhány darabja versben íródott, ám úgy érezte, ha a színpadon a szereplők versben beszélnek, az nem összeegyeztethető a mindennapi élettel, és így rontja a valósághüséget. Ezért prózára váltott, amely saját korában Európában is forradalmi lépésnek számított. A hétköznapi nyelvezet egy újabb olyan vonása az Ibsen-drámáknak, amelyet a kínai közönség a már említett okok miatt nagyra értékelt. Sokatmondó, hogy kínaira fordított életművéből szinte csak korai verses darabjai maradtak ki; ezek iránt a kínaiak nem érdeklödtek. ${ }^{33}$

Ibsen a körülmények egyszerü és valósághü ábrázolása, illetve a mindennapi szereplők hétköznapi nyelven előadott dialógusai segítségével drámái cselekményében az aktuális társadalmi valóságot akarta megjeleníteni. Ez volt az, ami a kínaiak számára adott történelmi helyzetükben létfontosságú volt. Az ibseni drámákat jellemző terminust, a „társadalmi problémadrámát” kínaira is lefordították, ez lett a shehui wenti ju 社会问题剧. A kínai társadalmi problémadráma jelentős müfajjá nőtte ki magát, és említésre méltó

33 He 2004: 74. 
helyet foglal el a modern kínai dráma történetében. A „Nóra-daraboknál” említett legtöbb mü itt is megállja a helyét, hiszen a társadalmi problémadrámák főhősei általában „Nóra jellegűek” voltak. Az 1920-as években túlnyomó részt ilyen darabok születtek. Rámutattak a kínai társadalmi és ideológiai rendszer elavult és fenntarthatatlan voltára, a szabadságra vágyó egyént szembeállítva az iránta ellenséges társadalommal. Az eddigieken túl megemlítendö Tian Han A tigris elfogásának éjszakája (Huohu zhi ye 获虎之夜, 1922) és Egy híres színész halála (Mingyou zhi si 名优之死, 1927), valamint Yu Shangyuan 余上沅 Lázadás (Bingbian 兵变, 1925) címü darabja.

Ezeknek a drámáknak, novelláknak és regényeknek a hősnői (és Ba Jin hőse) harcosokként jelennek meg, akik elutasítják a társadalom (és a család) egyéniséget megnyomorító voltát. Úgy döntenek, hogy felszabadítják saját magukat ezek alól a kötöttségek alól, és kilépnek az ismeretlenbe. Ezeket a darabokat gyakran „távozás-darabok" vagy departure-plays néven is emlegetik a szakirodalomban. Jellemző, hogy a hősnők a korszellemnek megfelelően bátran megteszik ezt a radikális lépést, de szembetűnő, hogy a drámaírókat kevésbé foglalkoztatta az a lélektani folyamat, amelynek során ezek a fiatal nők eljutnak az elhatározásig. A darabok többnyire rövidek, és a hősnő gondolataiba nem engednek mély bepillantást. Ibsen szemléletesen bemutatja Nóra örlődését, a harmadik felvonás végén pedig a férjével folytatott híres párbeszédben Nóra részletesen feltárja mindazt, amire nemrég ráébredt. „Megvilágosodása” bár hirtelen, de pszichológiailag alátámasztott.

\section{A „kínai Nórák”}

A Nóra kezdeti „utánzatai” között voltak jobb és kevésbé minőségi darabok. A termékeny, de múvészi színvonal szempontjából átmenetinek számító korszak jelentősége többek között abban áll, hogy ennek során a kínai közönség fokozatosan megismerte a huajut. Vízválasztó jelentőségü, hogy 1934-ben a modern kínai dráma máig legkiemelkedőbb alakjának tartott Cao Yu 曹禺 megírja Zivatar (Leiyu 雷雨) címü első darabját, amely már nem csupán formai kísérlet, hanem a nyugati dráma kínai környezetbe való átültetésének első igazi sikere. A Zivatar legendás hősnője, Zhou Fanyi 周㢣渏 vérbeli Nóra-figura, ám a korábbi, gyakran felületesen jellemzett, egysíkú nőalakokkal szemben egy nagy múvészi gonddal megrajzolt, ellentmondásos, húsvér asszony, igazi drámai egyéniség. Cao Yu második sikeres színdarabja, 
az 1936-ban bemutatott Napkelte (Richu 日出) hősnője, Chen Bailu 陈白露 is mutat ibseni jegyeket, és Zhou Fanyihoz hasonlóan ő is nagy formátumú nőalakja lett a modern kínai drámának. (He Chengzhou Chen Bailut Ibsen Hedda Gableréhez hasonlítja. ${ }^{34}$ )

Cao Yu, sok író kortársával ellentétben, a nyugati drámairodalom számos nagy mesterének műveit olvasta, és ezzel együtt Ibsent tartotta első számú példaképének. Ibsen realizmusa, a klasszikus drámai követelmények (például az arisztotelészi hármas egység) megjelenése müveiben, a retrospektív (viszszatekintő) expozició mind mély hatást tettek Cao Yure, aki saját drámáiban is sikeresen alkalmazta a mestertől tanult technikákat. Későbbi remekmüvében, a Pekingi emberekben (Beijing ren 北京人, 1940), bár alaphangulata inkább csehovi, szintén érezhetően jelen van Ibsen hatása. Nem utolsósorban, a lélektani karakterábrázolás is Cao Yu mủveiben érte el kínai csúcspontját. Zhang Lansheng megfogalmazása szerint a szakirodalomban Kína modern kori drámaírói közül Cao Yuröl tartják azt, hogy eszmei síkon a legjobban megértette, müvészi színvonalban pedig a leginkább megközelítette Ibsen drámai mủvészetét. ${ }^{35}$

Hu Shi szomorúan jegyezte meg, hogy bár Ibsen igazi csodadoktor, aki képes diagnosztizálni a társadalom minden betegségét, sajnálatos módon orvosságot nem írt fel a kikúrálásukra. ${ }^{36}$ Ibsen saját bevallása szerint szándékosan nem foglalkozott azzal, hogy miként alakul Nóra további sorsa. Nóra távozása egyértelmúen éles társadalomkritika, amit az író a végső párbeszédben - bár minden dagályos demagógia nélkül - Nóra szájába is ad. Nóra rálátott saját kiszolgáltatott voltára a családban és a társadalomban, és nem hajlandó tovább olyan világban élni, ahol az egyéniséget elnyomják, ahol a törvények és a vallás álszent módon uralkodnak és ítélkeznek a valódi erkölcsi értékek felett. Nóra a szemünk láttára alakul át szerény feleségből elszánt lázadóvá, végül pedig „nyíltan kihívja a férfi társadalmat”, ${ }^{37}$ amelynek képviseletében döbbent férje szóhoz sem jut. Ibsen céloz rá, hogy Nóra haza akar térni szülőfalujába, de semmi továbbit nem tudunk meg. Véleményem szerint Ibsen azért tartja a jövőt homályban, mert éreztetni akarja: nem az számít, hogy Nóra hogyan fogja (ha fogja egyáltalán) egymaga megreformálni

\footnotetext{
He 2004: 200.

Zhang 2005: 34.

He 2004: 19.

Yu 2013: 137.
} 
a társadalmat, hanem az, hogy mostani formájában kompromisszum nélkül elutasitja azt.

Hu Shi egyébként megérteni vélte Ibsen üzenetét. Megengedte, hogy a társadalom tünetei olyan sokfélék, hogy nem létezik orvosság, amely mindet egyszerre gyógyítja, de úgy gondolta, Ibsen válasza a társadalmi reform módjára mindenekelőtt az, hogy az Egyént hagyni kell a legteljesebb mértékben kiaknázni a benne rejlö tehetséget. ${ }^{38}$

Az, hogy a korai kínai „Nóra-darabok” sokszor gyakran szintén nem foglalkoznak a hősnő vagy az újdonsült fiatal szerelmespár további sorsával, hasonló megoldásnak tünik, ám akadtak, akik ezt a hiányosságot bírálták. Lu Xun 1923 decemberében emlékezetes előadást tartott egy pekingi női föiskolán „Nala zou hou zenmeyang? 娜拉走后怎么样?” (,Mi történik, miután Nóra elmegy?”) címmel. Ebben nem is annyira Ibsen Nórájáról, hanem a „kínai Nórákról" beszél. Véleménye szerint, amikor végletes döntést készülünk hozni, érzelmi felindultságunk közepette tekintetbe kell vennünk objektív tényezőket is. Nem lehet Ibsen „megoldását” egy az egyben átültetni kínai környezetbe, tudatában kell lennünk a nyugati és a kínai társadalom és kultúra között fennálló különbségeknek. Kínában egy nő számára, aki elhagyja a családját (chuzou 出走), semmiféle önfenntartó módszer nem létezik. A társadalmi megvetés, a gazdasági kilátástalanság felőrli, megfojtja a nehezen kivívott szabadságot. Lu Xun keserü felismerése: a megvilágosodottak tragédiája az, hogy az ébredés után nincs út, melyen elindulhatnak. Saját novellájában, az Elsiratásban éppen egy ilyen képet fest: ahogy az újdonsült fiatal pár szembesül a kitaszítottsággal, a szabadság varázsa megfakul, a nehézségek megrémítik őket. Végül a fiatalember kiábrándul, feladja, a lány hazatér a szülői házba, majd hamarosan meghal (vélhetőleg bánatában). Lu Xun arra int, hogy lázadásunk közepette is lássuk reálisan a társadalmi valóságot, amelyben élünk. A nők kilépése a családból szükségszerúen tragikus következményekkel jár egészen addig, amíg egy átfogó társadalmi reform nem ad nekik lehetőséget az önfenntartásra, más szóval a nők felszabadításának előfeltétele a társadalom felszabadítása. ${ }^{39}$ Ennek felismerése után, mondja Lu Xun, az író értelmiség felelőssége, hogy saját magát felhatalmazva ne buzdítsa a kínai nőket olyan modern viselkedésre, amelyhez nem értek még meg a társadalmi

\footnotetext{
38 Hou 1998: 138.
}

39 Li 2006: 52. 
viszonyok. ${ }^{40} \mathrm{~A}$ beszéd esszé formájában is megjelent, és még a '30-as években is társadalmi vita tárgya volt. Lu Xun azonban világossá tette álláspontját: mind elméleti írásaiban, mind novelláiban a józan előrelátás fontosságát hirdette. $^{41}$

Lu Xun mondanivalójában vitathatatlanul releváns az, hogy Nóra alakja, kínai földre lépve, elkerülhetetlen, hogy változáson menjen keresztül. És változáson is kell, hogy keresztülmenjen, hogy realista módon tudja tükrözni a kínai valóságot. Amikor a kínaiak Ibsent megismerve fellelkesülten tették magukévá az Ibsennek tulajdonított eszméket, azt látták meg leghangsúlyosabban Ibsenben, ami saját történelmi helyzetükben számukra a megoldást, a megmentő eszmét jelentette. A többit nagyvonalúan figyelmen kívül hagyták. Ibsen valóban felemelte a hangját az egyéniség védelmében, de munkássága, írói hitvallása ebben nem merült ki.

Elisabeth Eide szakmai körökben gyakran idézett, a Kina Ibsenje: Ibsentöl az ibsenizmusig címü 1987-es doktori disszertációjában jelentős különbséget tesz Ibsen mint író és az ibsenizmus mint társadalmi jelenség között:

„A kínaiak sosem azért olvasták Ibsent, hogy műveiben esztétikai megoldásokat találjanak irodalmi problémákra. Ök Ibsennel eleve az ibsenizmuson keresztül találkoztak, és az ibsenizmus határozta meg, mit fognak Ibsenben látni. A kínai kritikusok eklektikusok voltak, kiválogatva azokat a pozitív elemeket, amelyeket felhasználhattak egy új társadalom felépítéséhez. Ezek az elemek aztán pozitív sztereotípiákká váltak, és felszabadító erőként vettek részt a régi társadalommal szemben vívott harcban. Ibsen így maga egyenlővé vált az ibsenizmussal." ${ }^{42}$

Természetes jelenség, hogy egy irodalmi életmüben egy másik nemzet egy másik korban a számára aktuális mondanivalót keresi. Song Linsheng megfogalmazása szerint „az ibsenizmus hirdetése Kínában ébresztő célzatú, hatékonyságra törekvő, praktikus választás (yong de xuanze 用的选择) volt", 43 Kínának Ibsenre elsősorban társadalomfilozófusként és csak másodsorban drámaíróként volt szüksége. Ami azt illeti, Ibsenben a nyugati világ is társadalmi prófétát látott, többek között mint a feminizmus elszánt harcosát ünne-

\footnotetext{
40 Sanderson 2010: 34-35.

41 Li 2012: 60.

42 He 2004: 51.

43 Song 2010: 190.
} 
pelték. A Babaház, bár megosztotta a közönséget, a korabeli norvég feminista mozgalom körében például ujjongó fogadtatásra talált. Ibsen 1898-ban egy rövid, de tartalmas beszédben reagált erre. Szerényen megköszönte a feministák ünneplését, de kifejezte, némileg meg nem érdemeltnek érzi. Így nyilatkozott:

„Nem vagyok tagja a Női Jogok Ligának. Akármit is írtam, azt nem a tudatos társadalmi propagandaterjesztés szellemében tettem. Sokkal inkább költő, mint társadalomfilozófus vagyok, ellentétben azzal, amit most sokan hajlamosak gondolni rólam. Köszönöm az ünneplést, de vissza kell utasítanom azt a megtiszteltetést, miszerint tudatosan a nőjogi mozgalomnak dolgoztam volna. (...) Számomra ez az emberiséget érintő általános problémának tünik. (...) Valóban kívánatos lenne a nő-kérdést megoldani, az összes többivel egyetemben, de nekem nem ezt hirdetni volt a célom. Az én feladatom az, hogy az emberiséget fessem le. $(\ldots)^{\text {,44 }}$

Érdekes párhuzam, hogy Cao Yu, miután a Zivatar elsöprő sikere után a kritikusok és a közvélemény különféle nemes társadalmi missziók felvállalójaként ünnepelte, a később a Zivatarhoz füzött híres Elöszóban így nyilatkozott erröl:

„Sokan vannak, akik már helyettem megmagyarázták az okaimat. Ezek között a magyarázatok között van, amelyiket alá tudom írni. Ilyen például a »patriarchális nagycsalád büneinek leleplezése«. De visszaidézvén a három évvel ezelőtti hangulatomat, amikor is a Zivatart papírra vetettem, úgy érzem, nem lenne illendő kérkednem: nem gondoltam ki tudatosan, hogy én most majd megkritizálok, kigúnyolok vagy megtámadok valamit. Talán mire a darab elkészült, valamiféle kezdetben távoli, majd egyre hevesebb érzelmi hullám ragadott magával, és ekkor történhetett, hogy ahogy az elnyomással szembeni felháborodás úrrá lett rajtam, a hagyományos családi és társadalmi rendszer ellen fordultam." 45

Ibsen és Cao Yu mindketten tagadták, hogy tudatos szándékuk lett volna társadalmi propaganda kifejtése. Mint Ibsennél, Cao Yu múveinek is volt femi-

\footnotetext{
44 Sprinchorn 1964: 337-338.

45 Cao 2002: 180.
} 
nista olvasata, különösen, mivel Cao Yu szinte összes pozitív főhőse nö. Ennek ellenére mindkét drámaíró nyilatkozatából az hallik ki, hogy elsősorban az Ember ábrázolását tartják írói feladatuknak, és sokkal inkább humanista, mint feminista szemszögből szemlélik írásuk alanyait. Mikor Helmer emlékezteti Nórát, hogy „elsősorban nő és anya”, Nóra is így válaszol: „Már nem hiszem ezt. Elsősorban ember vagyok, akárcsak te." ${ }^{46}$

Ahogyan Ibsen és az ibsenizmus, He Chengzhou nézete szerint hasonlóképpen aránylik egymáshoz Ibsen Nóra-alakja és a kínai nóraizmus: „A nóraizmus Nóra kínai fogadtatása és átalakulása a kínai környezetben. Ez Nóra értelmezésének megváltozását jelenti, átformálva őt a kínai valóság szerint." ${ }^{, 47}$

A „kínai Nórák” íróik legjobb szándéka dacára több ponton különböznek Ibsen hősnőjétől. Annak oka, hogy kínai társnőivel szemben Ibsen Nórája a darab végén „elmehet”, és harca nincs eleve bukásra ítélve, szintén a Nyugat és a Kelet közötti történelmi, társadalmi és kulturális különbségekben keresendő. A korabeli Norvégia társadalma, még ha a fejlődő kapitalista viszonyok eredményeztek is torzulásokat az emberek látásmódjában és jellemében, még mindig több lehetőséget tartogatott egy egyedülálló asszony számára, mint a 20. század eleji, a nőket még mindig a férfiak tulajdonának tekintő kínai társadalom. ${ }^{48}$

Ez a függés a kínai „Nóra-darabokban” még az „önfelszabadítás” után is megjelenik. Míg Ibsen Nórája egyedül kell, hogy megélje a ráébredést, döntését egyedül hozza meg, és egymaga is távozik, kínai társnőinek legtöbbször támaszt jelent szerelmük bátorítása. A nyugati világgal ellentétben Kínában a nőknek sosem volt joguk a szabad párválasztáshoz: a jövendőbelit a szülők választották, egyik fiatalnak sem volt beleszólása. A haladó eszmék beáramlásával az új kultúra mozgalom eszmei tartalmában megjelent és jelentős súlyúvá vált a szabad szerelem és a szabad párválasztás igénye. Kínában az egyénnek a családban elfoglalt helye mindig is pontosan megfelelt a társadalomban betöltött szerepének: a család szerkezete a társadalmi hierarchia leképezése volt, tehát az atyai önkény a lánygyermek számára egyet jelen-

46 Ibsen 1966: 494

47 He 2004: 29.

48 Érdekes, hogy egyes kínai elemzők a Nórát is tragédiának tartják. Li Ruguo 李儒国 cikkében (2006: 50) így ír: „Nóra tragédiája nem a körülmények összejátszásának eredménye, hanem előre elrendelt és elkerülhetetlen." Úgy vélem, Ibsen darabjának végződése a legjobb indulattal is csupán homályos, Nóra sorsának tragikus alakulása korántsem olyan egyértelmü, mint a Zivatar Fanyijának örökké tartó szenvedése, lásd Li 2006. 
tett egyéni kiszolgáltatott szerepével, amelyet a társadalomban betölt. A „kínai Nórák” távozása tehát legtöbbször nem „öncélú”, hanem az atyai önkény alól akarnak felszabadulni, hogy szabadon választhassák ki párjukat.

Bár a Nóra nagyban hozzájárult a kínai nőjogi mozgalmak megerősödéséhez, kínai kontextusban Nóra alakja nem nélküli. Song Jianhua cikkében hosszasan elemzi Ibsen Nórája és a „kínai Nórák” „ébredése” közti különbséget: az előbbi a nyugati társadalmakban jellemző férfidominanciát törekszik levetni, hogy kivívhassa egyéni szabadságát, az utóbbiak pedig a kínai társadalomra specifikus apadominancia ellen küzdenek, hogy maguk választhassák meg jövendő életük párját. ${ }^{49}$ Véleményem szerint Ba Jin „férfi Nórája”, Gao Juehui nem pusztán érdekesség, „csodabogár” a kínai Nóra-irodalomban, hanem ékes bizonyítéka annak, hogy az elnyomás tárgya a 20. századi Kínában nem a nö, hanem az ember volt.

Ibsen Nórája azért nem maradhat, mert elvesztette hitét a házasságban, a társadalom törvényei és a vallás sem jelentenek már számára fogódzót, „tájékozódnia kell”; „látnia kell, kinek van igaza: a társadalomnak-e vagy neki”. ${ }^{50}$ Nóra azért távozik, hogy „megbirkózzon a saját maga megnevelésével”. ${ }^{51} \mathrm{~A}$ „kínai Nórák” „önállósága” viszonylagos: a nagy lépést is csak a „hátország” biztos tudatában teszik meg, és a legtöbb darabban a modern eszmék „müvelésében" is szerelmüktől (általában egy értelmiségi fiatalembertől) függenek. ${ }^{52}$ Abban, hogy a kínai hősnők számára fel sem merül az egyedül távozás lehetősége, valószínüleg mind a női lét kiszolgáltatottsága felett érzett bizonytalanság, mind a szabad szerelem iránti, eddig elnyomott vágy szerepet játszik, mely tényezők a kínai társadalom sajátosságaiból fakadnak.

Cao Yu hősnője, Zhou Fanyi olyan Nóra, aki végül nem megy el. Cao Yu megértette Ibsent: nem lemásolta őt, hanem saját társadalom- és világlátásához szabta, és a kínai valóságra alkalmazta a tỏle tanultakat. Ha elmegy, Fanyi csak Nóra kínai kiadása lett volna, és mint ilyen, a kínai társadalom számára nem lehetett volna hiteles alak. Így viszont egy hagyományos értékek és modern ideálok között vergődő fiatal nő, hiteles képviselője kora kínai aszszonyainak..$^{53}$ Cao Yu nőalakjainak dilemmája és ezek művészi megjelení-

\footnotetext{
49 Song 2011: 122.

50 Ibsen 1966: 494-495.

51 Ibsen 1966: 493.

52 Sanderson 2010: 34.

53 Luo 2016: 12.
} 
tése rendkívül összetett és jelentőségteljes szelete a modern kínai drámának; külön tanulmányt érdemel.

Kimondhatjuk, hogy Ibsen sokat „tett” a kínai drámáért: egy éppen megindult folyamatnak adott nagy lendületet. Az akkori kínai értelmiség úgy érezte, hogy az eszme, amelyet Ibsen megfogalmaz, lelkesít és kitartásra sarkall, átsegít a holtponton, és elindít a fejlődés útján. Nóra alakja generációknak adott erőt és ösztönzést az elnyomás elleni harcban. A minta, amelyet Ibsen társadalmi realista drámái nyújtottak, nagyban hozzájárult ahhoz, hogy az új kínai irodalom a társadalmi valóságot hitelesen ábrázolhassa. A modern kínai dráma és regény a 20. század második harmadától olyan életerôs fejlődést mutatott, mint ahogyan üde tavaszi eső után a felfrissült földből előtörnek az erős bambuszrügyek. ${ }^{54}$

\section{EIsődleges források}

Cao Yu 曹禺 2002. Leiyu 雷雨. Beijing: Remmin Wenxue Chubanshe.

Ibsen, Henrik 1966. Henrik Ibsen színmüvei. Második kötet. Budapest: Magyar Helikon.

\section{Másodlagos szakirodalom}

Chen Yanhong 陈燕红 - Li Bing 李兵 2006. „Xiaobona juzhong de Yibusheng zhuyi 萧伯纳剧中的易卜生主义 [Az ibsenizmus G. B. Shaw drámáiban].” Xinan Minzu Daxue Xuebao 西南民族大学学报 2006/6: 137-139.

Galla Endre 1986. „Korforduló a századfordulón. Beszélgetés a »nyitás« és »modernizálódás« kezdetéről.” Élet és tudomány 1986/43: 1354-1355.

Gao Yuejuan 高月娟 2006. „Nüxingzhuyi shijiao xia de Cao Yu chuangzuo 女性主义 视角下的曹禺创作 [Cao Yu életmüve feminista szemmel].” Shidai Wenxue 时代 文学 2006/6: 66-67.

He, Chengzhou 2004. Henrik Ibsen and Modern Chinese Drama. Oslo: Oslo Academic Press.

Hou Jian 侯健 (ed.) 1998. Hu Shi mingzuo xinshang 胡适名作欣赏 [Hu Shi híres müveinek méltatása]. Beijing: Zhongguo Heping Chubanshe.

Li Ruguo 李儒国 2006. „Cong Nala dao Fanyi kuitou liang ge nüxing de beiju mingyun 从娜拉到㢣猗窥透两个女性的悲剧命运 [Nórától Fanyi-ig: két nő tragikus sorsának áttekintése].” Hubei Guangbo Dianshi Daxue Xuebao 湖北广播电视大学 学报 23/5: 50-52.

54 Zhang 2005: 36 . 
Li Xinhao 李昕皓 2012. „You queshi dailai de sikao - cong Zhongshen dashi bing jiehe Lu Xun Nala zou hou zenyang tan dui wusi ,gexing jiefang” de renshi 由缺失带来 的思考 - 从《终身大事》并结合鲁迅《娜拉走后怎样》谈对五四 “个性解放” 的认识 [A veszteség ihlette reflexió - A május negyedike mozgalom egyéniségfelszabadító eszmeisége a Legnagyobb dolog az életben és Lu Xun Mi történik, miután Nóra elmegy? címü írásának tükrében]." Shanxi Meitan Guanli Ganbu Xueyuan Xuebao 山西煤炭管理干部学院学报 2012.25.2: 59-61.

Luo Xisha 罗茜莎 2016. „Cao Yu dui Yibusheng de jiejian he chaoyue. Yi Nala he Leiyu wei li 曹禺对易卜生的借鉴和超越 一 以《娜拉》和《雷雨》为例 [Ibsen Cao Yu számára: minta, amelyet követett és meghaladott. A Nóra és a Zivatar alapján].” Qingnian Wenxuejia 青年文学家 2016/18: 10-12.

Sanderson, Victoria 2010. Performing the Chinese Nora. Male-constructed Nora figures in Lu Xun's "Regret for the Past" and Mao Dun's "Creation” (B.A. diss., University of Sydney)

Song Jianhua 宋剑华 2011. „Cuowei de duihua: lun „Nala” xianxiang de Zhongguo yanshuo 错位的对话：论 “娜拉” 现象的中国言说 [A félreértett párbeszéd: a „Nórajelenség” értelmezése].” Wenxue Pinglun 文学评论 2011/1: 122-129.

Song Linsheng 宋林生 2010. „Yibusheng zhuyi: yi zhong xinxing de xiandaixing xiju huayu fanshi 《易卜生主义》: 一种新型的现代性戏剧话语范式 [Ibsenizmus: egy újfajta modern drámai diskurzus].” Renwen Zazhi 人文杂志 2010/2: 189-191.

Sprinchorn, Evert (ed.) 1964. Ibsen: Letters and Speeches. New York: Hill and Wang.

Yu Xiaoyan 余小艳 2013. „Nala, Fanyi xingxiang zhi bijiao 娜拉、繁猗形象之比较 [Nóra és Fanyi alakjának összehasonlítása].” Chuancheng 传承 2013.06: 136-137.

Zhang Lansheng 张兰生 2005. „Nala xianxiang” yu Leiyu 娜拉现象与《雷雨》[A „Nóra-jelenség” és a Zivatar].” Hebei Guangbo Dianshi Daxue Xuebao 河北广 播电视大学学报 2005.10.4: 33-36.

Zhang Xinmin 张新民 2004. „Yi nüxing yishi de shijiao guanzhao Cao Yu beijuzhong de nüxing renwu xingxiang 以女性意识的视角观照曹禺悲剧中的女性人物形象 [Cao Yu tragédiáinak nőalakjai a női öntudat szemszögéböl vizsgálva].” Henan Shifan Daxue Xuebao 河南师范大学学报 31/6: 120-122. 